\title{
TYPES OF AGGRESSIVE BEHAVIOR AMONG LEARNERS WITH MODERATE INTELLECTUAL DISABILITY IN NIGERIA AS PERCEIVED BY TEACHERS
}

\author{
Udeme Samuel Jacob ${ }^{1 a}$, Jace Pillay ${ }^{1 b}$, Esther Olufunke Oyefeso ${ }^{2 c}$, \\ ${ }^{1}$ University of Johannesburg, South Africa; ${ }^{2}$ University of Ibadan, Nigeria

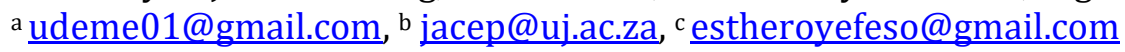

\begin{abstract}
This study examined aggressive behavior (verbal aggression, physical assault, socially unacceptable and destructive behavior) among learners with moderate intellectual disability in southwestern Nigeria, through teachers' perceptions. The study used a descriptive survey design. Convenient sampling technique was used to select respondents (87 teachers of pupils with intellectual ability in private and public schools in south West Nigeria). The aggressive behavior scale (ABS) was used to elicit responses. Data retrieved was analysed using descriptive and inferential statistics. Results showed that teachers' perception of the developmental trend of aggressive behavior among learners with moderate intellectual disability was significant $(\mathrm{T}=44.385$, Mean Difference $=3.115$ while $\mathrm{p}<.05$ ). Also, there was no significant gender difference in verbal aggressive ( $F=0.997, p>.05)$, physical aggressive $(\mathrm{F}=3.628, \mathrm{p}>.05)$, socially unacceptable aggressive $(\mathrm{F}=1.233, \mathrm{p}>.05)$, and destructive behavior $(\mathrm{F}=0.571, \mathrm{p}>.05)$. Interventions should be in line with these.
\end{abstract}

Keywords: aggressive behavior, developmental trend, learners with moderate intellectual disability, teachers' perception,

\section{INTRODUCTION}

Displaying aggressive behavior is a major obstacle to the social integration of individuals with intellectual disability. It affects their access to certain residential environments, educational and occupational programmes, and their general social acceptability (Harris, 1993; Bruininks et al., 1994). Due to the magnitude of the issue of aggressive behavior and the negative impact it has on the health of the children involved, it transcended institutional contexts to become a major public health problem (Shetgiri, 2013). Thus, to maintain a peaceful and safe school environment, stakeholders in education have tended to concern themselves with the problem of violence in our schools (Oyaziwo \& 
Adegoke, 2011). Moeller (2001) argued that aggression and aggressive behavior are two terms that are used interchangeably to describe negative feelings and behaviors. He added that aggressive behaviors are anti-social, and are viewed as morally, ethically, and legally unacceptable.

Aggression is described as an undesired attitude of individuals who force other people to accept their requests and exhibit hostile behaviors that are intended to harm or hurt others, or that causes fear in them (Başaran, 2000; Dodge et al., 2006). Such threats either results in, or have a high likelihood of resulting in injury, death, psychological harm, maldevelopment, or deprivation. Individuals who engage in aggressive behavior are at increased risk of victimization (Rusch et al., 1986) and criminalization (Lund, 1990; Crocker \& Hodgins, 1997; Logan-Greene et al., 2010). According to Wood et al. (2005), aggressive behavior is the intentional plan to harm others either physically or psychologically. De Almeida et al. (2015) view aggressive behavior as overt, but mostly harmful, social interaction with the intention to inflict damage or other unpleasantness upon another individual. Ferguson and Beaver (2009) added that aggressive behaviors are those which increase the social dominance of an organism relative to the dominance position of other organisms. Different types and expressions of aggressive behaviour must be observed because the causes and consequences of aggressive behaviour vary.

\section{LITERATURE REVIEW}

Aggression in Schools

Aggression directed at self or others is often a reason for referral to inpatient mental health services and poses a major obstacle to proper treatment (Gardner \& Moffat 1990; Cowley et al. 2005). Aggressive behavior should be taken seriously as it can have adverse consequences for the aggressor, such as seclusion or sedation, as well as for staff. In fact, 
aggression has been linked to burnout and stress among staff and it can affect the therapeutic environment negatively (Edwards \& Miltenberger 1991; Hunter \& Carmel 1992). These consequences warrant a closer examination of aggressive behaviors in treatment facilities for persons with intellectual disability. Knowledge and understanding of their nature, extent and circumstances is an important first step towards better tailored services and will help staff to better cope with these behaviors.

Aggressive behavior in persons with intellectual disability and its correlates have been examined in several studies (McClintock et al., 2003). These studies showed, although not consistently, that men (Sigafoos et al., 1994), persons aged between 20 and 35 years (Tyrer et al., 2006), persons with more severe levels of intellectual disability (Crocker et al., 2006; Tyrer et al., 2006), and persons with a history of violence (Davidson et al., 1994; Linaker, 1994), are most likely to show aggression. Besides, aggressive behavior appears to be associated with an increased prevalence of psychopathology (Moss et al. 2000; Hemmings et al., 2006). Furthermore, aggressive behavior is often assessed in samples that are heterogeneous in terms of the level of intellectual disability, age, or setting (Sigafoos et al., 1994; Crocker et al., 2006; Tyrer et al., 2006).

Once children attend pre-school education institutions and begin to interact with their peers extensively, aggression becomes an important issue. Children adopt different compliance strategies when confronted with difficult situations, among them being aggressive behavior (Chen et al., 2010; Hockenberry et al., 2016). It is crucial to find ways to effectively manage early childhood conduct problems so that they do not lead to violence and different types of aggression later in life (Farrington \& Welsh, 2007; Karaca \& İkiz, 2014). 


\section{Types of Aggressive behavior}

According to Poggenpoel and Myburgh (2002), aggression can be expressed through behaviors that are both constructive and destructive. Constructive aggression can be used for individual and collective welfare. Destructive aggression is disturbing for individuals and groups and is disruptive. Essau and Conradt (2004) developed a typology of aggressive behavior explaining different types of aggression, such as open aggression, hidden aggression, reactive aggression, proactive aggression, relational aggression, and instrumental or hostile aggressions. Although studies on the prevalence of aggressive behavior have been conducted, there remains a dearth of knowledge on aggressive behavior in school settings. In most reported studies, aggressive behavior and its characteristics were assessed retrospectively (Crocker et al., 2006; Tyrer et al., 2006).

Investigation of various forms of aggressive behavior by Whitney and Smith (1993) and Owens et al. (2000), revealed that the most common and frequent forms are insults, name-calling, yelling at others, theft, hitting, threats, and social exclusion. Different studies have revealed that male adolescents display higher aggressive behavior than their female counterparts, whereas other studies have failed to find gender differences in aggressive behavior (Archer, 2004; Leenaars \& Rinaldi, 2010). Concerning gender differences, Crick (1996) and Crick and Grotpeter (1995), argued that aggressive behaviors in girls have been overlooked because they are seen from a different perspective than those of their male counterparts.

Imhonde (2013) argued that aggression is exhibited in different forms among individuals, such as physical, mental, or verbal manifestations. Physical abuse has repeatedly been linked to delinquency and interpersonal violence in adolescence (Manly et al., 2001; Smith \& Thornberry, 1995). Youth who are victims of abuse are at greater risk of 
themselves becoming abusive in adulthood (Fang \& Corso, 2007). Goodenough (1931) asked mothers of 2- to 5-year-olds to record the details of their children's angry outbursts in a diary. When he examined the data, Goodenough found that unfocused temper tantrums become less and less common between the ages of two and three as children began to physically retaliate (by hitting or kicking) when playmates frustrated or attacked them.

\section{Physical aggressive behavior}

Children often have heightened sensitivity to rejection derived from early experiences of physical abuse or emotional neglect that then triggers anxiety or angry states (Dodge et al., 1990). Previous studies identified serious risk factors among pupils with impaired development as aggressive behavior, victimization, and perpetration (Barnow et al., 2005; Smith et al., 2003) with effects extending into adult roles and functioning (Brown et al., 2007; Liu \& Kaplan, 2004). Lochman et al. (1990), examined social cognitive variables in aggressive and nonaggressive boys at pre-adolescent and early adolescent developmental points. They found that aggressive children often misread interpersonal cues by interpreting ambiguous or pro social communication as hostile and, therefore, reacted aggressively.

Slaby and Guerra (1988) elaborated on the cognitive profile of these aggressive adolescents who believed that there were limited consequences for aggression, that aggression had concrete benefits, and that it was a legitimate response. These findings are exceedingly important as understanding the impact of impaired social communication can assist families in dealing with violent outbursts and serve as the basis for developing potential interventions. Within the context of supportive relationships with adults who act as a buffer against any negative effects of instability, children learn how to cope with adversity, adapt to their 
surroundings, and regulate their emotions (National Scientific Council on the Developing Child, 2007). Extreme levels of stress can be detrimental to children's mental health and cognitive functioning (Evans et al., 2011; Shonkoff \& Garner, 2011). Instability has been studied from various angles, with the underlying theme that certain kinds of change, and changes at certain points in their lives, predict negative outcomes for children (Moore et al., 2000). These changes do not occur in isolation.

\section{Developmental trend based on aggressive behavior}

Various scientific studies have revealed different perspectives on the causes of violence. Despite claims that people's aggression motivation is innate (Lorenz, 2008; Yörükoğlu, 2002), Bandura (1977) argued that children learn both aggressive and non-aggressive behaviors by observing and modeling others. Victimization and perpetration of aggression have been repeatedly linked (Maas et al., 2008) across multiple types of victimization. The character of children's aggression changes dramatically with age. Physical aggression, however, gradually declined between ages three and five, only to be replaced by teasing, tattling, name-calling, and other forms of verbal aggression. Adolescents who witness violence in their homes are more likely to become violent or aggressive themselves (Kracke, 2001; Reppucci et al., 2002). A more recent study sought to characterize developmental change in physical aggression from toddlerhood to middle childhood (NICHD Early Child Care Research Network, 2004). This study of 1,195 children used mothers' reports of the children's levels of physical aggression, assessed each year from when the children were aged 2 to when they were 9.

There are also links between victimization and later revictimization (Desai et al., 2002; Finkelhor et al., 2007). Negative outcomes of victimization (Arata, 2002; Classen et al., 2001) indicate that victimization and trauma play a central role in the development and persistence of 
violent perpetration, although multiple mechanisms for this relationship have been proposed (Falshaw et al., 1996). Coupled with recent advances in the study of toxic stress and its adverse effects on child development (National Scientific Council on the Developing Child, 2007), there is a growing need to understand what it means for children to experience instability and how negative effects can be prevented.

\section{Gender differences and aggressive behavior}

Gender is said to have an impact on various levels of adolescence and can also affect reaction to the disposition of others, leading to aggression. Although higher rates have generally been found among men than among women (Harris, 1992; Harris, 1993; Borthwick-Duffy, 1994; Davidson et al., 1994; Maccoby \& Jacklin, 1974), research on this showed that girls' aggressive tactics included gossip, ostracism, breaking confidences, and criticism of victim's clothing, appearance, or personality (Owens et al., 2000). Girls rate such aggression as more hurtful than boys, suggesting their heightened sensitivity to it (Galen \& Underwood, 1997). It is not until the age of $2 \frac{1}{2}$ to 3 that sex differences in aggression are reliable, and this is clearly enough time for gender typing to have steered boys and girls in different directions (Fagot et al., 1992). The reason for this could be that parents' play with boys is rougher than with girls, and they react more negatively to the aggressive behaviors of daughters than to those of sons (Mills \& Rubin, 1990; Parke \& Slaby, 1983).

During their preschool years, children come to view aggression as a male attribute in their gender schemas, and by middle childhood, boys expect aggressive acts to provide them with benefits that are more tangible and which will elicit less disapproval from either parents or peers than girls' experience (Herzberger \& Hall, 1993; Perry et al., 1989). In their literature review, McClintock et al. (2003) found that males were more likely than females to display aggression. This result was, however, 
based on only two studies. Moreover, most studies have focused on more severe forms of aggression, and gender differences or similarities are unknown for lower levels of aggression. In a study on the influence of gender and personality features of violent behavior among adolescents in Nigeria, it was found that gender had no significant influence on violent behavior and personality traits (agreeableness, neuroticism, openness to experience, extraversion and conscientiousness), but had a significant influence on violent behavior among adolescents (Mokolapo \& Dele, 2014).

\section{METHOD}

The present study used a descriptive survey design through which the researchers attempt to quantitatively describe how teachers perceive types of aggressive behavior of learners with moderate intellectual disability. This was achieved by administering a questionnaire to determine how teachers of learners with moderate intellectual disability depict aggressive behavior.

\section{Purpose of the Study}

The goal of developing appropriate intervention strategies that would assist children with intellectual disability that have been exposed to one form of aggression or another should be done after the type and magnitude of aggressive behavior has been determined. The purpose of the study is, therefore, to examine aggressive behavior among learners with moderate intellectual disability in South-western Nigeria using teachers' perceptions.

\section{Research questions}

1. Is teachers' perception of physical aggression among learners with moderate intellectual disability significantly different? 
2. Is teachers' perception of developmental trend of aggressive behavior among learners with moderate intellectual disability significant?

3. Is there any significant difference in teachers' perception of gender and types of aggressive behavior among learners with moderate intellectual disability?

4. Is there any significant difference between teachers' perception of gender based aggressive behavior and school type among learners with moderate intellectual disability?

\section{Participants}

The study respondents were teachers who taught pupils with intellectual disability in 8 private and 14 public schools in South West Nigeria $($ male $=36$; female $=51$; age range $=24-60$ years $)$. Three states were randomly selected out of the six states in South West Nigeria. The convenient sampling technique was used for the selection of teachers from schools for learners with moderate intellectual disability to ensure geographical coverage. Written consent forms were utilized. All responses were anonymous and confidential.

\section{Instrument}

The aggressive behavior scale (ABS) was a 4-item summary that measured verbal aggression (screaming at others), physical assault (hitting others), socially unacceptable and destructive behavior (throwing things), and resistance to care (shoving of caregivers). The frequency of ABS items was coded over 7 days as: not exhibited (0); behavior occurred 1 to 3 days over the past 7 days (1); behavior occurred 4 to 6 days over the past 7 days, but not more than daily (2); or behavior occurred daily (3) (Andres et al., 2017). ABS scores ranged from 0 to 12, with higher scores suggesting most behaviors occurred at a higher frequency. The average inter-rater reliability estimates for all behavior items on the MDS 
2.0 was excellent, with a kappa of 0.72 (Morris et al., 1997). This instrument was used because of its ability to capture the constructs of interest (i.e., teachers' perceptions and the presence of aggressive behavior) and age appropriateness (6-15 years).

\section{Ethical Considerations}

Respondents were duly informed about the objectives of the study. After adequate explanation of the purpose of the research in line with the ethics of research, a consent form written in English was printed and given to each respondent. These needed to be signed before they could complete the online research instrument on Google form.

\section{Method of Data Analysis}

The data retrieved was analysed using descriptive and inferential statistics. The descriptive statistics (percentage, mean and standard deviation) was used to analyse the demographic data of the respondents. Inferential statistics (t-test) was used to analyse the hypotheses at 0.05 level of significance.

\section{RESULTS}

Table 1 shows the demographic characteristic of the teachers who responded to the questionnaire about their perception of aggressive behavior among learners with moderate intellectual disability.

Table 1: Teacher Demographics

\begin{tabular}{|l|r|r|r|r|}
\hline & \multicolumn{1}{|c|}{$\mathrm{N}$} & \multicolumn{1}{|c|}{ Percentage } & \multicolumn{1}{c|}{ Mean } & Std. Deviation \\
\hline Age range & $\mathbf{8 7}$ & & $\mathbf{4 . 2 6}$ & $\mathbf{1 . 9 8 5}$ \\
\hline below 24 years & 10 & 11.5 & & \\
\hline $25-29$ years & 11 & 12.6 & & \\
\hline 30 -34 years & 10 & 11.5 & & \\
\hline $35-39$ years & 15 & 17.2 & & \\
\hline $40-44$ years & 11 & 12.6 & & \\
\hline
\end{tabular}


Jacob, U.S., Pillay, J., Oyefeso, E.O., (2021). TYPES OF AGGRESSIVE BEHAVIOR AMONG LEARNERS WITH MODERATE INTELLECTUAL DISABILITY IN NIGERIA AS PERCEIVED BY TEACHERS. Jurnal Tatsqif, 19 (1), 41-66. https://doi.org/10.20414/itq.v19i1.3260

\begin{tabular}{|l|r|r|r|r|}
\hline $45-49$ years & 16 & 18.4 & & \\
\hline 50 years and above & 14 & 16.1 & & \\
\hline School type & $\mathbf{8 7}$ & & $\mathbf{1 . 5 6}$ & $\mathbf{4 9 9}$ \\
\hline Private school & 38 & 43.7 & & \\
Public school & 49 & 56.3 & & $\mathbf{4 9 5}$ \\
Gender & $\mathbf{8 7}$ & & $\mathbf{1 . 5 9}$ & \\
Male & 36 & 41.4 & & \\
Female & 51 & 58.6 & & \\
\hline Valid N (listwise) & $\mathbf{8 7}$ & & & \\
\hline
\end{tabular}

Descriptive statistics of frequency counts and simple percentage was used to analyse the demographic data collected from the respondents. The analysis showed that 10 of the teachers $(11.5 \%)$ were 24 and younger, 11 (12.6\%) were 25-29, 10 (11.5\%) were 30-34, 15 (17.2\%) were 35-39, 11 (12.5\%) were 40-44, 16 (18.4\%) were 45-49, and 14 (16.1\%) were 50 and above. This showed that most of the respondents were between 45 and 49. Furthermore, the table revealed that 38 $(43.7 \%)$ of the teachers worked in private schools, while $49(56.3 \%)$ were employed in public schools. Information based on gender distribution revealed that 51 (58.8\%) of the respondents were female and 36 (41.4\%) were male. This indicated that there were more females than males employed as teachers.

Is teachers' perception of physical aggression among learners with moderate intellectual disability significantly different?

Table 2. One-sample t-test comparing the test assumed mean with the mean of teachers perception on items of physical aggression

\begin{tabular}{|c|c|c|c|c|c|}
\hline \multicolumn{6}{|c|}{ Test Value $=0$} \\
\hline \multirow[t]{2}{*}{$\mathrm{T}$} & \multirow[t]{2}{*}{$\mathrm{df}$} & \multirow{2}{*}{$\begin{array}{l}\text { Sig. (2- } \\
\text { tailed) }\end{array}$} & \multirow{2}{*}{$\begin{array}{c}\text { Mean } \\
\text { Difference }\end{array}$} & \multicolumn{2}{|c|}{$95 \%$ Confidence Interval of the Difference } \\
\hline & & & & Lower & Upper \\
\hline 47.115 & 86 & .000 & 3.368 & 3.23 & 3.51 \\
\hline
\end{tabular}


Table 2 shows the one-sample t-test comparing the test assumed mean with the mean of teachers' perceptions on items of physical aggression (where $\mathrm{t}=47.115$, Mean Difference $=3.368$, while $p>.05$ ). The result shows that teachers' perceptions of physical aggression among learners with moderate intellectual disability is significant. Teachers' perceptions of physical aggressive behavior among learners with moderate intellectual disability is significant.

Is teachers' perception of the developmental trend of aggressive behavior among learners with moderate intellectual disability significant?

Table 3. One-sample t-test comparing the test assumed mean with the mean of teachers perception of developmental trend of aggressive behavior items

\begin{tabular}{|c|r|r|r|r|r|}
\hline \multicolumn{9}{|c|}{ Test Value $=0$} \\
\hline $\mathrm{T}$ & \multicolumn{1}{|c|}{ df } & \multirow{2}{*}{$\begin{array}{l}\text { Sig. (2- } \\
\text { tailed) }\end{array}$} & \multirow{2}{*}{$\begin{array}{c}\text { Mean } \\
\text { Difference }\end{array}$} & \multicolumn{2}{|c|}{ 95\% Confidence Interval of the Difference } \\
\cline { 5 - 6 } & & & Lower & \multicolumn{2}{|c|}{ Upper } \\
\hline 44.385 & 86 & .000 & 3.115 & 2.98 & 3.25 \\
\hline
\end{tabular}

Table 3 shows the one-sample t-test comparing the test assumed mean with the mean of teachers' perceptions on items of the developmental trend of aggressive behavior, where $(t=44.385$, Mean Difference $=3.115$ while $p>.05$ ). The result shows that teachers' perception of the developmental trend of aggressive behavior among learners with moderate intellectual disability is significant.

Is there any significant difference in teachers' perception of gender and types of aggressive behavior among learners with moderate intellectual disability?

Table 4. Teachers' perception of gender according to T-Test Results for aggressive behavior types

\begin{tabular}{|l|l|r|r|r|r|r|}
\hline & Gender & \multicolumn{1}{c|}{ df } & \multicolumn{1}{c|}{ Mean } & \multicolumn{1}{c|}{ t } & \multicolumn{1}{c|}{ F } & \multicolumn{1}{c|}{ Sig. } \\
\hline \multirow{2}{*}{ Developmental trend } & Male & & 2.97 & -1.795 & & \\
\cline { 2 - 7 } & Female & 85 & 3.22 & -1.776 & .997 & .321 \\
\hline \multirow{2}{*}{ Physical } & Male & & 3.39 & .330 & & \\
\cline { 2 - 7 } & Female & 85 & 3.35 & .320 & 3.628 & .060 \\
\hline \multirow{2}{*}{ Socially unacceptable } & Male & & 2.97 & .445 & & \\
\cline { 2 - 7 } & Female & 85 & 3.22 & .466 & 1.233 & .270 \\
\hline \multirow{2}{*}{ Destructive } & Male & & 3.39 & .082 & & \\
\cline { 2 - 7 } & Female & 85 & 3.35 & .085 & .324 & .571 \\
\hline
\end{tabular}


Table 4 shows no significant gender-based difference in verbal aggressive behavior ( $F=0.997, p<.05)$. Nevertheless, the table also revealed that females had a mean of 3.22, which was higher than that of the mean of their male counterparts at 2.97, indicating that females had more verbal aggressive behavior than males. The hypothesis was, therefore, accepted. While Table 4 also shows no significant gender difference in physical aggressive behavior ( $F=3.628, p<.05)$, males had a higher mean of 3.39 than that of their female counterparts at 3.35 , indicating that males had more physical aggressive behavior than females. Therefore, the hypothesis is accepted. Table 4 also shows no significant gender difference in socially unacceptable aggressive behavior $(\mathrm{F}=1.233, p<.05)$, however, females had a higher mean of 3.22 than their male counterparts with a mean of 2.97, indicating that females exhibited more socially unacceptable aggressive behavior. Therefore, the hypothesis is accepted. It was also revealed that while there was no gender difference in destructive behavior $(F=0.571, p>.05)$, Table 4 shows that males had a higher mean of 3.39 than their female counterparts, who had a mean of 3.35, indicating that males exhibited more destructive aggressive behavior than females. Therefore, gender based aggressive behavior is not significantly different.

Is there any significant difference between teachers' perception of gender based aggressive behavior and school type among learners with moderate intellectual disability?

Table 5. Perception of aggressive types According to T-Test Results for gender Independent Samples Test

\begin{tabular}{|l|l|r|r|r|r|r|}
\hline \multirow{2}{*}{ Aggressive behavior } & School type & \multicolumn{1}{c|}{ df } & \multicolumn{1}{c|}{ Mean } & \multicolumn{1}{c|}{ t } & \multicolumn{1}{c|}{ F } & \multicolumn{1}{c|}{ Sig. } \\
\hline \multirow{3}{*}{ Verbal } & Private schools & 85 & 2.89 & -2.813 & .037 & .847 \\
\cline { 2 - 7 } & Public schools & & 3.27 & -2.709 & & \\
\hline Socially unacceptable & Private schools & 85 & 3.42 & .572 & 3.569 & .062 \\
\cline { 2 - 7 } & Public schools & 85 & 2.89 & -2.813 & .037 & \\
\hline
\end{tabular}


Jacob, U.S., Pillay, J., Oyefeso, E.O., (2021). TYPES OF AGGRESSIVE BEHAVIOR AMONG LEARNERS WITH MODERATE INTELLECTUAL DISABILITY IN NIGERIA AS PERCEIVED BY TEACHERS. Jurnal Tatsqif, 19 (1), 41-66. https://doi.org/10.20414/itq.v19i1.3260

\begin{tabular}{|l|l|r|r|r|r|r|}
\hline & Public school & 85 & 3.42 & .577 & .583 & .447 \\
\hline \multirow{3}{*}{ Destructive behavior } & Private schools & & 3.33 & .218 & & \\
\cline { 2 - 7 } & Public school & 85 & 2.89 & .215 & .805 & .372 \\
\hline
\end{tabular}

Table 5 shows that there was no significant difference in school type and verbal aggressive behavior ( $\mathrm{F}=0.037, p<.05)$. It also showed that public schools had a higher mean of 3.27 than their private school counterparts, which had a mean of 2.89 , indicating that public schools had more verbal aggressive behavior than private schools. Table 5 showed no significant difference in school type in physical aggressive behavior $(\mathrm{F}=$ $3.569, p<.05)$. It was, however, revealed that private schools had a mean of 3.42 and public schools a mean of 2.89 , indicating that private schools had more physical aggression than public schools. In addition, while no significant difference in socially unacceptable behavior by school type was found ( $\mathrm{F}=0.447, p<.05)$, public schools had a higher mean of 3.42 than that of their counterparts in private schools with a mean of 3.27. This indicated that public schools had more socially unacceptable aggressive behavior than private schools. Table 5 also revealed that there is no significant difference in school type in destructive aggressive behavior ( $F=0.805, p>.05)$. Private schools, however, had a higher mean of 3.33 than their public school counterparts with a mean of 2.89, indicating that private schools had more destructive aggressive behavior than public schools. Therefore, gender based aggressive behavior is not significant with school type among adolescent with intellectual disability.

\section{DISCUSSION OF FINDINGS}

The results show that teachers' perception of physical aggression among learners with moderate intellectual disability is significant. This is consistent with the submission of Imhonde (2013), who argued that aggression could be exhibited in different forms among individuals, such as by physical, mental, or verbal manifestations. Dodge et al. (1990), asserted that children often have heightened sensitivity to rejection 
derived from early experiences of physical abuse or emotional neglect, which then triggers anxiety or angry states. Aggression can also be expressed through both constructive and destructive behaviors (Poggenpoel \& Myburgh, 2002). The reasons for this are that children often misread interpersonal cues and interpret ambiguous or prosaic communication as hostile and react aggressively. These findings align with the assertion of Manly et al. (2001), and Smith and Thornberry (1995) that physical abuse has repeatedly been linked to delinquency and interpersonal violence in adolescence.

The result also reveals that teachers' perception of the developmental trend of aggressive behavior among learners with moderate intellectual disability is significant. This is supported by the notion that victimization and perpetration of aggression have been repeatedly linked across multiple types of victimization (Maas et al., 2008). The character of children's aggression changes dramatically with age. To explain these findings, one starts with the preschool period during which learners with moderate intellectual disability have not reached a level of cognitive and emotional development to achieve their goals using negotiation strategies or other less aggressive verbal methods of conflict resolution. By the time pupils reached school-going age, however, the expectation of researchers was that emotional self-regulation and language skills - which could be used in problem solving strategies - would already be developed. This was not so, which may be due to the pupils' intellectual disability that had impacted on their cognitive development and their use of adaptive skills.

There was no significant difference in teachers' perception between gender and types of aggressive behavior among learners with moderate intellectual disability. The reason for this, as argued by Crick (1996) and Crick and Grotpeter (1995), is that aggressive behaviors in girls have been overlooked because they are seen from a different perspective than those of their male counterparts. The finding does, however, align with 
previous studies that failed to discern gender differences in aggressive behavior (Archer, 2004; Leenaars \& Rinaldi, 2010). McClintock et al. (2003), disagree, finding that males were more likely than females to display aggression.

There was no significant difference in teachers' perception based on school type and aggressive behavior of learners with moderate intellectual disability. The findings do not align with the submission of Moore et al (2000), who noted that changes at certain points in the lives of persons with intellectual disability had negative outcomes for the children. This is because school type did not change the teachers' perception of aggressive behavior among the study sample. Based on the findings it is, therefore, recommended that interventions to curb aggressive behavior in learners with moderate intellectual disability should cut across males and females as they are equally affected. Moreover, since learners with moderate intellectual disability in both public and private schools have the tendency to display aggressive behavior, appropriate management techniques should be adopted.

\section{CONCLUSION}

This study concludes that there was significant difference between teachers' perception and physical aggression among learners with moderate intellectual disability. The reason may be due to instability that this group of pupils generally experienced, both cognitively and emotionally. The study revealed that teachers' perceptions of the developmental trend of aggressive behavior among learners with moderate intellectual disability is significant. It is, therefore, important to provide appropriate intervention focused on curbing aggressive behavior among learners with moderate intellectual disability. There was no significant gender difference in verbal aggressive behavior, physical aggressive behavior, socially unacceptable aggressive behavior, and 
destructive behavior. Therefore, appropriate interventions must focus on both male and female learners with moderate intellectual disability. Also, it was shown that there was no significant difference in school type regarding verbal aggressive behavior, physical aggressive behavior, socially unacceptable behavior, and destructive aggressive behavior. School-based interventions to curb aggressive behavior must be provided at both public and private schools.

\section{CONFLICT OF INTEREST}

The authors confirm that there is no conflict of interest with respect to the data presented in this paper.

\section{FUNDING}

This work was supported by the South African Research Chairs Initiative of the Department of Science and Innovation and National Research Foundation of South Africa. South African Research Chair: Education and Care in Childhood: Faculty of Education: University of Johannesburg South Africa [grant number: 87300, 2017].

\section{ACKNOWLEDGMENTS}

The authors acknowledge the students who responded to their instruments and the authors whose materials they consulted.

\section{REFERENCES}

Andres, E., Kerling, F., Hamer, H., Kasper, B., \& Winterholler, M. (2017). Behavioural changes in patients with intellectual disability treated with perampanel. Acta Neurological Scandinavica, 136(6), 645-653. https://doi.org/10.1111/ane.12781 
Jacob, U.S., Pillay, J., Oyefeso, E.O., (2021). TYPES OF AGGRESSIVE BEHAVIOR AMONG LEARNERS WITH MODERATE INTELLECTUAL DISABILITY IN NIGERIA AS PERCEIVED BY TEACHERS. Jurnal Tatsqif, 19 (1), 41-66. https://doi.org/10.20414/itq.v19i1.3260

Arata, C. M. (2002). Child sexual abuse and sexual revictimization. Clinical Psychology: Science and Practice, 9(2), 134-164. https://doi.org/10.1093/clipsy.9.2.135

Archer, J. (2004). Sex differences in aggression in real-world settings: A metaanalytic review. Review of General Psychology, 8(4), 291-322. https://doi.org/10.1037/1089-2680.8.4.291

Bandura, A. (1977). Self-efficacy: Toward a unifying theory of behavioral change. Psychological Review, 84(2), 191-215. https://doi.org/10.1037/0033-295X.84.2.191

Barnow, S., Lucht, M., Freyberger, H. J. (2005). Correlates of aggressive and delinquent conduct problems in adolescence. Aggressive Behavior, 31(1), 24-39. https://doi.org/10.1002/ab.20033

Başaran, İ. E. (2000). Eğitim Yönetimi. Nitelikli Oku [Educational psychology]. Feryal Matbaası.

Borthwick-Duffy, S. A. (1994). Prevalence of destructive behaviors: A study of aggression, self-injury, and property destruction. In T. Thompson \& D. B. Gray (Eds.), Destructive behavior in developmental disabilities: Diagnosis and treatment (pp. 3-23). Sage.

Brown, G. W., Craig, T. K. J., Harris, T. O., Handley, R. V., \& Harvey, A. L. (2007). Development of retrospective interview measure of parental maltreatment using the Childhood Experience of Care and Abuse (CECA) instrument - A life-course study of adult chronic depression. Journal of Affective Disorders, 103(1-3), 205-215. https://doi.org/10.1016/j.jad.2007.05.022

Bruininks R. H., Olson, K. M., Larson, S. A., \& Lakin, K. C. (1994) Challenging behaviors among persons with mental retardation in residential settings. In T. E. Thompson \& D. B. E. Gray (Eds), Destructive behavior in developmental disabilities: Diagnosis and treatment (pp. 23-48). Sage.

Chen, X., Huang, X., Chang, L., Wang, L., \& Li, D. (2010). Aggression, social competence, and academic achievement in Chinese children: A 5-year 
Jacob, U.S., Pillay, J., Oyefeso, E.O., (2021). TYPES OF AGGRESSIVE BEHAVIOR AMONG LEARNERS WITH MODERATE INTELLECTUAL DISABILITY IN NIGERIA AS PERCEIVED BY TEACHERS. Jurnal Tatsqif, 19 (1), 41-66. https://doi.org/10.20414/jtq.v19i1.3260

longitudinal study. Development and Psychopathology, 22(3), 583-592. https://doi.org/10.1017/S0954579410000295

Classen, C., Field, N. P., Koopman, C., Nevill-Manning, K., \& Spiegel, D. (2001). Interpersonal problems and their relationship to sexual revictimization among women sexually abused in childhood. Journal of Interpersonal Violence, 16(6), 495-509. https://doi.org/10.1177/088626001016006001

Cowley, A., Newton, J., Sturmey, P., Bouras, N., \& Holt, G. (2005) Psychiatric inpatient admissions of adults with intellectual disabilities: Predictive factors. American Journal on Mental Retardation 110(3), 216-225. https://doi.org/10.1352/0895-8017(2005)110<216:PIAOAW>2.0.C0;2

Crick, N. R. (1996). The role of overt aggression, relational aggression, and prosaical behavior in the prediction of children's future social adjustment. Child Development, 67(5): 2317-2327. https://doi.org/10.2307/1131625

Crick, N. R., Grotpeter, J. K. (1995). Relational aggression, gender, and socialpsychological adjustment. Child Development, 66(3), 710-722. https://doi.org/10.2307/1131945

Crocker, A. G., \& Hodgins, S. (1997). The criminality of non-institutionalized mentally retarded persons: Evidence from a birth cohort followed to age 30. Criminal Justice and Behavior, 24(4), 432-454. https://doi.org/10.1177/0093854897024004003

Crocker, A. G., Mercier, C., Lachapelle, Y., Brunet, A., Morin, D., \& Roy, M.-E. (2006). Prevalence and types of aggressive behaviour among adults with intellectual disabilities. Journal of Intellectual Disability Research, 50(9), 652-661. https://doi.org/10.1111/j.1365-2788.2006.00815.x

Davidson, P. W., Cain, N. N., Sloane-Reeves, J. E., Van Speybroech, A., Segel, J., Gitkin, J., Quijano, L. E., Kramer, B. M., Porter, B., Shoham I., \& Goldstein, E. (1994). Characteristics of community-based individuals with mental 
retardation and aggressive behavioral disorders. American Journal of Mental Retardation, 98(6), 704-716.

De Almeida, R. M, Cabral, J. C, Narvaes, R. (2015). Behavioral, hormonal and neurobiological mechanisms of aggressive behaviour in human and nonhuman primates. Physiology \& Behavior, 143, 121-135. https://doi.org/10.1016/j.physbeh.2015.02.053

Deptula, D. P., \& Cohen, R. (2004). Aggressive, rejected, and delinquent children and adolescents: A comparison of their friendships. Aggression and Violent Behavior, 9(1), 75-104. https://doi.org/10.1016/S1359$\underline{1789(02) 00117-9}$

Desai, S., Arias, I., Thompson, M. P., Basile, K. C. (2002). Childhood victimization and subsequent adult revictimization assessed in a nationally representative sample of women and men. Violence and Victims, 17(6), 639-653. https://doi.org/10.1891/vivi.17.6.639.33725

Dodge, K. A., Bates, J., \& Pettit, G. S. (1990). Mechanisms in the cycle of violence. $\quad$ Science, 250(4988), 1678-1683. https://doi.org/10.1126/science.2270481

Dodge, K. A., Coie, J. D., \& Lynam, D. (2006). Aggression and antisocial behavior in youth. In N. Eisenberg, D. William, \& R. M. Lerner (Eds.), Handbook of child psychology: Social, emotional and personality development (6th ed.), (pp. 719-788). Wiley.

Edwards, P., \& Miltenberger, R. (1991). Burnout among staff members at community residential facilities for persons with mental retardation. Mental Retardation, 29(3), 125-128.

Essau, C.A., Conradt, J. (2004). Agresivnost kod djece i mladih [Aggression in children and adolescents]. Naklada Slap.

Evans, G. W., Brooks-Gunn, J., \& Klebanov, P. K. (2011). Stressing out the poor: Chronic physiological stress and the income-achievement gap. Community Investments, 23(2), 22-27. 
Fagot, B. I., Leinbach, M. D., \& O’Boyle, C. (1992). Gender labeling, gender stereotyping, and parenting behaviors. Developmental Psychology, 28(2), 225-230. https://doi.org/10.1037/0012-1649.28.2.225

Falshaw, L., Browne, K. D., Hollin, C. R. (1996). Victim to offender: A review. Aggression and Violent Behavior, 1(4), 389-404. https://doi.org/10.1016/S1359-1789(96)00005-5

Fang, X., Corso, P. S. (2007). Child maltreatment, youth violence, and intimate partner violence: Developmental relationship. American Journal of Preventive Medicine, 33(4), 281-290. https://doi.org/10.1016/j.amepre.2007.06.003

Farrington, D. P., \& Welsh, B. C. (2007). Saving children from a life of crime: Early risk factors and effective interventions. Oxford University Press.

Ferguson, C. J., Beaver, K. M. (2009). Natural born killers: The genetic origins of extreme violence. Aggression and Violent Behavior, 14(5): 286-294. https://doi.org/10.1016/j.avb.2009.03.005

Finkelhor, D., Ormrod, R. K., Turner, H. A. (2007). Polyvictimization and trauma in a national longitudinal cohort. Development and Psychopathology. 19(1), $149-166$. https://doi.org/10.1017/S0954579407070083

Galen, B. R., Underwood, M. K. (1997). A developmental investigation of social aggression among children. Developmental Psychology, 33(4), 589-600. https://doi.org/10.1037/0012-1649.33.4.589

Gardner, W. I., \& Moffat, C. W. (1990). Aggressive behaviour: Definition, assessment, treatment. International Review of Psychiatry, 2(1), 91-100. https://doi.org/10.3109/09540269009028275

Goodenough, F. L. (1931). Anger in young children. University of Minnesota Press.

Harris, M. (1992). Language experience and early language development: From input to uptake. Erlbaum. 
Harris, P. (1993). The nature and extent of aggressive behaviour amongst people with learning difficulties (mental handicap) in a single health district. Journal of Intellectual Disability Research 37, 221-242. https://doi.org/10.1111/j.1365-2788.1993.tb01281.x

Hemmings, C. P., Gravestock, S., Pickard, M., \& Bouras, N. (2006). Psychiatric symptoms and problem behaviours in people with intellectual disabilities. Journal of Intellectual Disability Research, 50(4), 269-276. https://doi.org/10.1111/j.1365-2788.2006.00827.x

Herzberger, S. D., \& Hall, J. A. (1993). Consequences of retaliatory aggression against siblings and peers: Urban minority children's expectations. Child Development, 64(6), 1773-1785 https://doi.org/10.1111/j.14678624.1993.tb04212.x

Hockenberry, M. J., Wilson, D., \& Rogers, C. (2016). Wong's essentials of pediatric nursing. Elsevier.

Hunter, M., \& Carmel, H. (1992). The cost of staff injuries from inpatient violence. Hospital and Community Psychiatry, 43, 586588. https://doi.org/10.1176/ps.43.6.586

Imhonde, H. 0. (2013). Self-esteem, gender, family-communication-style and parental neglect as predictors of aggressive tendencies among Secondary School adolescents. International Journal of Public Health Science, 2(3): 93-100. https://doi.org/10.11591/ijphs.v2i3.2873

Karaca, R., \& İkiz, F. E. (2014). A contemporary understanding in guidance and psychological counselling. Nobel Yayınevi.

Kracke, K. (2001). Children's exposure to violence: The Safe Start Initiative. [0JJDP Fact Sheet, April, \#13]. U.S. Department of Justice. http://www.ncjrs.gov/pdffiles1/ojjdp/fs200113.pdf

Leenaars, L., Rinaldi, C. M. (2010). Male and female university students' experiences of indirect aggression. Canadian Journal of School Psychology, 25(1), 131-148. https://doi.org/10.1177/0829573509350062 
Jacob, U.S., Pillay, J., Oyefeso, E.O., (2021). TYPES OF AGGRESSIVE BEHAVIOR AMONG LEARNERS WITH MODERATE INTELLECTUAL DISABILITY IN NIGERIA AS PERCEIVED BY TEACHERS. Jurnal Tatsqif, 19 (1), 41-66. https://doi.org/10.20414/itq.v19i1.3260

Linaker, O. M. (1994). Assaultiveness among institutionalised adults with mental retardation. British Journal of Psychiatry, 164(1), 62-68. https://doi.org/10.1192/bjp.164.1.62

Liu, R. X., \& Kaplan, H. B. (2004) Role stress and aggression among young adults: The moderating influences of gender and adolescent aggression. Social Psychology Quarterly, 67(1), 88-102. https://doi.org/10.1177/019027250406700108

Lochman, J. E., Coie, J. D., Underwood, M. K., \& Terry, R. (1993). Effectiveness of a social relations intervention program for aggressive and nonaggressive, rejected children. Journal of Consultation Clinical Psychology, 61(6), 1053-1058. https://doi.org/10.1037//0022$\underline{006 x \cdot 61.6 .1053}$

Logan-Greene, P. L., Nurius, P. S., Herting, J. R., Walsh, E., \& Thompson, E. A. (2010). Violent victimization and perpetration: Joint and distinctive implications for adolescent development. Victims \& Offenders, 5(4), 329353. https://doi.org/10.1080/15564886.2010.509655

Lorenz, K. (2008). Here's the human (V. Atayman; E. Güney, Çev.). Yeni Gün Haber Ajansı Basın ve Yayıncılık A. Ş.

Lund, J. (1990). Mentally retarded criminal offenders in Denmark. British Journal of Psychiatry, 156(5), 726-731. https://doi.org/10.1192/bjp.156.5.726

Maas, C., Herrenkohl, T. I., Sousa, C. (2008). Review of research on child maltreatment and violence in youth. Trauma, Violence, \& Abuse, 9(1), 56-67. https://doi.org/10.1177/1524838007311105

Maccoby, E. E., \& Jacklin, C. N. (1974). The psychology of sex differences. Stanford University Press.

Manly, J. T., Kim, J. E., Rogosch, F. A., Cicchetti, D. (2001). Dimensions of child maltreatment and children's adjustment: Contributions of developmental timing and subtype. Development \& Psychopathology, 13(4):759-782. https://doi.org/10.1017/S0954579401004023 
Jacob, U.S., Pillay, J., Oyefeso, E.O., (2021). TYPES OF AGGRESSIVE BEHAVIOR AMONG LEARNERS WITH MODERATE INTELLECTUAL DISABILITY IN NIGERIA AS PERCEIVED BY TEACHERS. Jurnal Tatsqif, 19 (1), 41-66. https://doi.org/10.20414/itq.v19i1.3260

McClintock, K., Hall, S., \& Oliver, C. (2003). Risk markers associated with challenging behaviours in people with intellectual disabilities: A metaanalytic study. Journal of Intellectual Disability Research, 47(6), 405416. https://doi.org/10.1046/j.1365-2788.2003.00517.x

Mills, R. S. L., \& Rubin, K. H. (1990). Parental beliefs about problematic social behaviors in early childhood. Child Development, 61(1), 138-151. https://doi.org/10.1111/j.1467-8624.1990.tb02767.x

Moeller, T. G. 2001. Youth aggression and violence: A psychological approach. Routledge.

Mokolapo, O. T., \& Dele, J. T. (2014). Influence of gender and personality characteristics on violent behavior among adolescents in Nigeria. Asian Journal of Humanities and Social Studies, 2(1), 179-185. https://www.ajouronline.com/index.php/AJHSS/article/view/621

Moore, K. A., Vandivere, S., \& Macomber, J. E. (2000). Turbulence and child well-being. Urban Institute. https://www.urban.org/research/publication/turbulence-and-childwell-being

Morris, J. N., Nonemaker, S., Murphy, K., Hawes, C., Fries, B. E., Mor, V., \& Phillips, C. (1997). A commitment to change: Revision of HCFA's RAI. Journal of the American Geriatrics Society, 45(8), 1011-1016. https://doi.org/10.1111/j.1532-5415.1997.tb02974.x

Moss, S., Emerson, E., Kiernan, C., Turner, S., Hatton, C., \& Alborz, A. (2000). Psychiatric symptoms in adults with learning disability and challenging behaviour. British Journal of Psychiatry, 177(5), 452-456. https://doi.org/10.1192/bjp.177.5.452

National Scientific Council on the Developing Child. (2007). Excessive stress disrupts the architecture of the developing brain: Working paper no. 3. Center on the Developing Child, Harvard University. http://developingchild.harvard.edu/index.php/resources/reports and working papers/working_papers/wp3/ 
NICHD Early Child Care Research Network. (2001). Child care and children's peer interaction at 24 and 36 months: The NICHD study of early child care. Child $\quad$ Development, 1478-1500. https://doi.org/10.1111/1467-8624.00361

Owens, L., Shute, R., \& Slee, P. (2000). "I'm in and you're out...|"Explanations for teenage girls' indirect aggression. Psychology, Evolution \& Gender; 2(1), 19-46. https://doi.org/10.1080/14616660050082906

Oyaziwo, A., \& Adegoke, A. A. (2011). Managing bullying problems in Nigerian secondary schools: Some counselling interventions for implementation. Nigerian Journal of Guidance and Counselling, 15(1). https://doi.org/10.4314/njgc.v15i1.64660

Parke, R. D., \& Slaby, R. G. (1983). The development of aggression. In P. H. Mussen (Ed.), Handbook of child psychology, Vol. 4: Socialization, personality, and social development (4th ed.), pp. 547-641). Wiley.

Perry, D. G., Perry, L. C., \& Weiss, R. J. (1989). Sex differences in the consequences that children anticipate for aggression. Developmental Psychology, 25(2), 312-319. https://doi.org/10.1037/0012$\underline{1649.25 .2 .312}$

Poggenpoel, M., Myburgh, C. P. H. (2007). Lived-experience of aggression in Secondary Schools in South Africa. Education, 123, 161-166.

Reppucci, N. D., Fried, C. S., Schmidt, M. G. (2002). Youth violence: Risk and protective factors. In: R. R. Corrado, R. Roesch, S. D. Hart, \& J. K. Gierowski (Eds.), Multi-problem violent youth (pp. 3-22). IOS Press.

Rusch, R. G., Hall, J. C. \& Griffin, H. C. (1986) Abuse-provoking characteristics of institutionalized mentally retarded individuals. American Journal of Mental Deficiency, 90(6), 618-624.

Shetgiri, R. (2013). Bullying and victimization among children. Advances in Pediatrics, 60(1), 33-51. https://doi.org/10.1016/i.yapd.2013.04.004 
Jacob, U.S., Pillay, J., Oyefeso, E.O., (2021). TYPES OF AGGRESSIVE BEHAVIOR AMONG LEARNERS WITH MODERATE INTELLECTUAL DISABILITY IN NIGERIA AS PERCEIVED BY TEACHERS. Jurnal Tatsqif, 19 (1), 41-66. https://doi.org/10.20414/itq.v19i1.3260

Shonkoff, J. P \& Garner, A. S. (2011). The lifelong effects of early childhood adversity and toxic stress. Pediatrics, 129(1), e232-e246. https://doi.org/10.1542/peds.2011-2663

Sigafoos, J., Elkins J., Kerr, M., \& Attwood, T. (1994). A survey of aggressive behaviour among a population of persons with intellectual disability in Queensland. Journal of Intellectual Disability Research, 38(4), 369-381. https://doi.org/10.1111/j.1365-2788.1994.tb00417.x

Slaby, R. G., \& Guerra, N. G. (1988). Cognitive mediators of aggression in adolescent offenders. Developmental Psychology, 24(4), 580-588. https://doi.org/10.1037/0012-1649.24.4.580

Smith, C., Thornberry, T. P. (1995). The relationship between childhood maltreatment and adolescent involvement in delinquency. Criminology, 33(4), 451-481. https://doi.org/10.1111/j.1745-9125.1995.tb01186.x

Smith, P. H., White, J. W., Holland, L. J. (2003). A longitudinal perspective on dating violence among adolescent and college-age women. American Journal of Public Health, 93(7), 1104-1109. https://doi.org/10.2105/ajph.93.7.1104

Tyrer, F., McGrother, C. W., Thorp, C. F., Donaldson, M., Bhaumik, S., Watson, J. M., \& Hollin, C. (2006). Physical aggression towards others in adults with learning disabilities: Prevalence and associated factors. Journal of Intellectual Disability Research, 50(4), 295-304. https://doi.org/10.1111/j.1365-2788.2005.00774.x

Whitney, I., \& Smith, P. K. (1993). A survey of the nature and extent of bullying in junior/middle and secondary schools. Educational Research, 35(1), 3-25. https://doi.org/10.1080/0013188930350101

Wood, S. E, Wood, E. G, \& Boyd, D. (2005). The world of psychology. Pearson Education.

Yörükoğlu, A. (2002). Aggression in children. Çoluk Çocuk Anne Baba Eğitimci Dergisi, 11, 14-15. 